\title{
WHY I HATE AUGUST
}

ROBERT K. MURPHY, Department of Biology, University of Nebraska at Kearney, Kearney, NE 68849, E-mail: <murphyrk@unk.edu>

Next to the house this evening there are about 3,000 swallows packed on only two power lines that stretch maybe $70 \mathrm{~m}$. They're mostly Tree Swallows, but some Barn, Cliff, and Bank Swallows are there, too. Adding it up quickly in my head that's nearly 150 pounds of swallow; the power lines sway ever so faintly under their weight. In the slough below, young American Coots whimper and whistle plaintively for food from tending adults, mother Gadwalls and Ruddy Ducks paddle with their broods of half-grown young through the duckweed, and a family of Pied-billed Grebes presses the edge of the marsh grasses like a fleet of half-submerged submarines. Aside from the steady grasshopper refrain, swallow gossip, and a melancholy chorus of coot chicks, the prairie is quiet. The evening sun is hot, the air still. Dragonflies and damselflies are aloft everywhere, big blue and black ones and small gold ones mostly, hovering and darting in the air, a menace to any mosquito or midge that happens by. An Eastern Kingbird scolds harshly somewhere in the distance, and I imagine it harrying some unlucky young swallow that's just happened by. Wood-Nymphs drift by on gray, dusky wings worn and faded like those of other July butterflies. Marbled Godwits, Upland Sandpipers, and the many sparrows that infused the air with calls and songs only weeks ago are now gone. Gaudy prairie lilies and pastel coneflowers have surrendered to blazing stars, asters, and goldenrods, and the needlegrasses and wheatgrasses have cured and almost stopped growing. Massive cumulus clouds build on the horizon, gray ominous billows with sinister streaks of ashen white below that say hail and rain are being dumped into the next county.

It's August again, the end of nesting season on the prairie. It's my least favorite time of year, the anticlimax over which I lament and even disdain while struggling with impatient anticipation of fall and all the wonderful things it brings before winter hastens life away, downwind, to places south. Spring on the northern prairie is sensational but so short. It's an explosion: it's there, then it's over, too fast. We yearn for it for months, the quintessential rebirth. Spring on the prairie is birds; lots of them, everywhere. Some wing high overhead, arctic-bound or perhaps holding course for a tract of spruce and fir in northern Saskatchewan. Others settle to defend breeding territories, singing as they have for millennia and will yet while there's still some prairie left. Spring is early mornings, late evenings, the days increasingly longer until twilight stretches nearly to midnight; lengthy evening shadows, with the blessed smell of musty grass, damp soil, and dank humus coalesced in cool air masses, drifting downslope; the clamor of chorus frogs and Mallard ducks everywhere; blissfully cool days, the last patches of snow, frosts still on some May and even June mornings. That's the prairie in spring. That's what some of us live for: biologists, 
ranchers, naturalists, wildlife enthusiasts, all of us prairie freaks who are somehow wedded to native grasslands and sloughs.

l've tried to put my finger on it, why summer seems so sad and the spring before so joyous. It lately struck me that spring is a dear old friend, a wondrous old friend who I look forward to being with. It's anticipation of my friend's arrival, the remembering of old times together: exhilaration, renewal, escape, adventure, discovery. Each year, my friend visits and then leaves. The stay lasts weeks, almost months, but the end is overpowering and unavoidable, the departure gradual but certain. I'm reminded I can only experience so many springs on the prairie. They are so fine I want them all; I want to horde them somehow, but they are fleeting. That is why I hate August. It is farewell.

\section{FALL BIRDS}

Sun streaming

through golden leaves

this evening

and a tumult of birds

gathering strength in our yard

a fall frenzy

alternately feeding and bathing

preening, shaking out their plumes

in wonderful disarray.

Despite the urgency of migration

still the robins bicker and chase

as if they didn't have enough

to do this night.

\section{- Bob Nero}

